\title{
SUMBER-SUMBER ZAT GIZI DAN PENILAIAN STATUS GIZI
}

NURLITA

Universitas Islam Negeri Alauddin Makassar

Email: nurlitaa24@gmail.com

\section{SUMBER ZAT GIZI}

1. Kecukupan Pangan untuk Memenuhi Karbohidrat

- Kontribusi energi dari karbohidrat terhadap asupan (kecukupan) energi : 50-

$60 \%$.

- Pendekatan PPH (Pola Pangan Harapan) :

[?] Kontribusi energi dari karbohidrat $=61 \%$ AKE, dipenuhi dari kelompok pangan :

? VSeralia $=50 \%$; ?VUmbi2an $=6 \%$; ? VGula $=5 \%$

?] Kebutuhan pangan sumber karbohidrat :

? $\vee$ Seralia $=275 \mathrm{~g} / \mathrm{kap} / \mathrm{hr}$ setara beras (jenis pangan a.I beras, jagung, jagung muda dan gandum ? bahan penukar)

? V Umbi2an = $100 \mathrm{~g} / \mathrm{kap} / \mathrm{hr}$ setara ubi jalar (jenis pangan a.I ubi kayu dan olahannya, ubi jalar, sagu, kentang ? bahan penukar)

? $\sqrt{ }$ Gula $=30 \mathrm{~g} / \mathrm{kap} / \mathrm{hr}$ setara gula pasir (jenis pangan a.l gula pasir, gula merah $\sim$ bahan penukar)

Untuk memenuhi 61 \% AKE $2000 \mathrm{kkal} / \mathrm{kap} / \mathrm{hr}$ (WNPG, 2004)

2. Kecukupan Pangan untuk Memenuhi Lemak

- Pendekatan PPH (Pola Pangan Harapan) :

[?] Kontribusi energi dari lemak = $13 \%$ AKE, dipenuhi dari kelompokpangan :

? V Minyak \& lemak $=10 \%$

? V Buah/Biji Berminyak = $3 \%$

]? Kebutuhan pangan sumber lemak:

? V Kelompok Minyak \& lemak = $20 \mathrm{~g} / \mathrm{kap} / \mathrm{hr}$ setara minyakgoreng

(jenis pangan a.I minyak kelapa, minyak kacang tanah, minyak goreng, lemak hewani bahan penukar) 
? V Kelompok Buah/Biji Berminyak $=10 \mathrm{~g} / \mathrm{kap} / \mathrm{hr}$ setara kelapa

(jenis pangan a.I Kelapa)

Untuk memenuhi 13 \% AKE $2000 \mathrm{kkal} / \mathrm{kap} / \mathrm{hr}$ (WNPG, 2004)

3. Kebutuhan Pangan untuk memenuhi Protein

- Pendekatan PPH (Pola Pangan Harapan) :

?? $\sim$ Kontribusi energi dari protein $=17 \%$ AKE , dipenuhi dari kelompok pangan :

? V Pangan hewani $=12 \%$

? $\vee$ Kacang-kacangan $=5 \%$

[?] Kebutuhan pangan sumber lemak:

? $\sqrt{ }$ Kelompok Pangan hewani $=150 \mathrm{~g} / \mathrm{kap} / \mathrm{hr}$ setara daging sapi

(jenis pangan a.I Daging, ikan, telur, susu?bahan penukar)

?V Kelompok Kacang-kacangan $=35 \mathrm{~g} / \mathrm{kap} / \mathrm{hr}$ setara kedelai

(jenis pangan a.l kacang tanah, kacang kedelai, kacang hijau, kacang merah bahan penukar)

Untuk memenuhi 17 \% AKE $2000 \mathrm{kkal} / \mathrm{kap} / \mathrm{hr}$ (WNPG, 2004)

4. Kecukupan Pangan untuk memenuhi Vitamin dan Mineral

- Pangan sumber vitamin \& mineral = sayur \& buah.

- Berdasarkan pendekatan PPH maka kebutuhan sayur \& buah = $250 \mathrm{~g} / \mathrm{kap} / \mathrm{hr}$ setara dengan kontribusi energi sebesar $6 \%$ AKE (2000 kkal/kap/hr, WNPG, 2004).

\section{PENILAIAN STATUS GIZI}

Ada dua metode penilaian status gizi ini yaitu 1) Penilaian status gizi Langsung terdiri dari Antropometri, Pemeriksaan Klinis, Biokimia, dan Biofisik, 2) Tidak Langsung terdiri dari Survei Konsumsi Makanan, Statistik Vital, Faktor Ekologi.

\section{Penilaian Status Gizi Secara Langsung}

\section{Antropometri}

Antropometri digunakan untuk melihat ketidakseimbangan asupan protein dan energi (karbohidrat dan lemak). Keunggulan antropometri : Alat mudah, dapat dilakukan berulang-ulang \& objektif, siapa saja bisa dilatih mengukur, relatif murah, hasilnya mudah disimpulkan, secara ilmiah diakui kebenarannya, sederhana, aman, bisa sampel besar, tepat, akurat, dapat menggambarkan riwayat gizi masa lalu, dan bisa untuk skrining, dan mengevaluasi status gizi. Kelemahan antropometri meliputi : tidak sensitif \& spesifik mengukur suatu zat gizi, bisa dipengaruhi faktor diluar gizi misalnya penyakit, bisa terjadi kesalahan 
pengukuran. Antropometri sebagai indikator status gizi dapat dilakukan dengan mengukur beberapa parameter. Parameter ini terdiri dari :

Antropometri menggunakan parameter yang terdiri dari :

a. Umur, yaitu bulan penuh untuk anak 0-2 tahun dan tahun penuh $>2$ tahun dihitung dari hari lahir, misalnya bayi usia 6 bulan 10 hari dihitung usia 6 bulan atau anak umur 8 tahun 4 bulan dihitung 8 tahun.

b. Berat Badan menggunakan timbangan yang sesuai dan cara yang tepat,

c. Tinggi Badan diukur pada posisi lurus dengan cara yang tepat,

d. Lingkar Lengan Atas dapat menggunakan pita LILA atau meteran,

e. Lingkar Kepala,

f. Lingkar dada, dan

g. Jaringan lunak (lemak sub cutan) diukur menggunakan alat khusus.

Parameter sebagai ukuran tunggal belum bisa digunakan untuk menilai status gizi harus dikombinasikan. Kombinasi beberapa parameter disebut Indeks Antropometri yang terdiri dari :

1) Berat badan menurut umur (BB/U),

2) Tinggi badan menurut umur (TB/U),

3) Berat badan menurut tinggi badan (BB/TB),

4) Lingkar lengan atas menurut umur(LLA/U),

5) Indeks Massa Tubuh (IMT)

Setiap indeks antropometri memiliki kelebihan dan kelemahan masing-masing seperti tampak pada matrik berikut ini :

- $B B / U$

Kelebihan : Mudah, cepat dimengerti, bisa mengukur status akut \& kronis, sensitif thd perubahan, dpt mendeteksi overweigh.

Kelemahan : Dipengaruhi ascites/udema, harus tahu jelas tanggal lahir, sering salah dalam pengukuran.

- TB/U

Kelebihan : Alat mudah murah, fleksibel, bisa mengukur gizi masa lampau

Kelemahan : Tinggi badan lambat berubah, posisi harus tepat, umur harus pasti.

- $\mathrm{BB} / \mathrm{TB}$

Kelebihan : Tidak perlu data umur, dapat membedakan proporsi badan gemuk, normal, kurus

Kekurangan : Tidak memberikan gambaran tinggi anak menurut seumuran, sulit dilakukan pada balita, alat ukur 2 macam, lebih lama, sering terjadi kesalahan pengukuran. 
- LLA/U

Kelebihan : Baik utk menilai Kekurangan Energi Protein (KEP) berat, murah, mudah.

Kelemahan : Sulit menentukan ambang batas, sulit menilai pertumbuhan anak 2-5 thn.

\section{Pemeriksaan Fisik}

Pemeriksaan fisik dapat dilakukan melalui teknik inspeksi atau periksa pandang, palpasi atau periksa raba, perkusi atau periksa ketuk dan auskultasi atau pemeriksaan menggunakan stateskop. Semua perubahan pada rambut, kulit, mata,mulut, lidah, gigi, kelenjar tiroid, dll. Menurut Jelliffe dan Jelliffe, tanda-tanda klinis dapat dikelompokkan dalam tiga kelompok besar yaitu

a .Kelompok 1, tanda-tanda yang memang benar berhubungan dengan kurang gizi bisa karena kekurangan salah satu zat gizi atau kelebihan dari yang dibutuhkan tubuh,

b. Kelompok 2, tanda-tanda yang membutuhkan investigasi atau penyelidikan lebih lanjut karena tanda ini mungkin saja merupakan tanda gizi salah atau mungkin disebabkan faktor lain, dan

c.Tanda-tanda yang tidak berkaitan dengan gizi salah walaupun hampir mirip, untuk dapat menentukannya diperlukan keahlian khusus.

Untuk dapat mengelompokan tanda-tanda yang ada pada pasien, pemeriksa harus mengetahui tanda-tanda dan gejala akibat kekurangan atau kelebihan setaip zat gizi. Kita ambil salah satu contoh pemeriksaan pada mata :Tanda-tanda pemeriksaan pada mata yang masuk kelompok 1 atau berhubungan dengan kekurangan gizi misalnya : konjungtiva anemis, keratomalasia, angular palpebritis, sedangkan masuk kelompok 2 yang mungkin berhubungan dengan kekurangan gizi misalnya : corneal vascularization, infeksi konjungtiva, arcus kornea, xanthomata, corneal scars. Tanda-tanda yang masuk kelompok 3 adalah pterygium.

\section{Pemeriksaan Klinis}

Pemeriksaan klinis sebagai salah satu metode penilaian status gizi secara langsung, secara umum terdiri dari dua bagian yaitu 1) riwayat medis / riwayat kesehatan merupakan catatan mengenai perkembangan penyakit, 2) pemeriksaan fisik, yaitu melakukan pemeriksaan fisik dari kepala sampai ujung kaki untuk melihat tanda-tanda dan gejala adanya masalah gizi. Kita mulai dari riwayat medis. Dalam riwayat ini kita mencatat semua kejadian yang berhubungan dengan gejala yang timbul pada penderita beserta faktor-faktor yang mempengaruhinya. Catatan kita haruslah meliputi identitas penderita secara lengkap, riwayat kesehatan saat ini, riwayat kesehatan masa lalu yang berkaitan dengan penyakit saat ini, riwayat kesehatan keluarga yang berkaitan, data lingkungan fisik dan sosial budaya yang berhubungan dengan gizi, data-data tambahan yang diperlukan misalnya adalah riwayat alergi terhadap makanan, jenis diet dan pengobatan yang sedang atau pernah dijalani pasien,dll. Data-data tersebut dapat dikumpulkan melalui wawancara dengan penderita dan keluarga. Seperti pada metode penilaian status gizi yang lain, pemeriksaan fisik juga memiliki kekurangan dan kelebihan. Kelebihan atau keunggulannya adalah relatif murah, tidak memerlukan tenaga khusus cukup paramaedis terlatih, sederhana, cepat, dan mudah diiterpretasikan, dan peralatan sederhana sedangkan kelemahannya adalah Beberapa gejala klinis tidak mudah dideteksi, kadang tidak spesifik, adanya gejala klinis yang bersifat multipel, gejala dapat terjadi saat permulaan atau tahap akan sembuh dari penyakit, adanya variasi dalam gejala klinis. 


\section{Biokimia}

Pemeriksaan biokimia zat gizi terdiri dari 1) penilaian status besi dengan pemeriksaan Haemoglobin (Hb), Hematokrit, Besi serum, Ferritin serum, saturasi transferin, free erytrocites protophoprin, unsaturated iron-binding capacity serum, 2) penilaian status protein dapat dilakukan dengan melakukan pemeriksaan fraksi protein yaitu Albumin, Globulin, dan Fibrinogen, 3) penilaian status vitamin tergantung dari vitamin yang ingin kita ketahui misalnya vitamin A dinilai dengan memeriksa serum retinol, vitamin $D$ dinilai dengan pemeriksaan kalsium serum, vitamin $E$ dengan penilaian serum vitamin E, vitamin Cdapat dinilai melalui pemeriksaan perdarahan dan kelainan radiologis yang ditimbulkannya, menilai status riboflavin (B2) dengan pemeriksaan kandungan riboflavin dalam urine, niasin dinilai dengan pemeriksaan nimetil nicotamin urine. Begitu juga dengan vitamin-vitamin yang lain. Untuk mineral misalnya iodium dinilai dengan memeriksa kadar yodium dalam urine dan kadar hormon TSH ( thyroid stimulating hormone), Zink atau seng dinilai dengan pemeriksaan urine, atau kandungannya dalam plasma, Kalsium dengan memeriksan serum kalsium, begitu juga dengan mineral-mineral yang lain. Hasil pemeriksaan biokima setiap zat gizi tersebut dibandingkan dengan nilai normalnya masing-masing sehingga bila dibawah nilai normal berarti terdapat kekurangan sebaliknya bila diatas nilai normal bisa jadi karena kelebihanzat gizi tertentu

\section{Biofisik}

Penentuan status gizi dengan biofisik adalah melihat dari kemampuan fungsi jaringan dan perubahan struktur. Tes kemampuan fungsi jaringan meliputi kemampuan kerja dan energi ekspenditure serta adaptasi sikap. Tes perubahan struktur dapat dilihat secara klinis ( misalnya pengerasan kuku, pertumbuhan rambut, dll) atau non klinis (misalnya radiologi). Penilaian secara biofisik dapat dilakukan dengan tiga cara yaitu 1) uji radiologi, 2) tes fungsi fisik (misalnya tes adaptasi pada ruangan gelap), dan 3) sitologi (misalnya pada KEP dengan melihat noda pada epitel dari mukosa oral). Penilaian biofisik ini memerlukan biaya yang besar.

\section{Penilaian Status Gizi Tidak Langsung}

\section{Survei konsumsi makanan}

Survei ini digunakan dalam menentukan status gizi perorangan atau kelompok. Survei konsumsi makanan dimaksudkan untuk mengetahui kebiasaan makan atau gambaran tingkat kecukupan bahan makanan dan zat gizi pada tingkat kelompok, rumah tangga dan perorangan serta faktor-faktor yang mempengaruhinya. Berdasarkan jenis data yang diperoleh, pengukuran konsumsi makanan menghasilkan dua jenis data yaitu kualitatif ( a.I frekuensi makanan, dietary history, metode telepon, dan daftar makanan) dan data kuantitatif (Metode recall 24 jam, perkiraan makanan, penimbangan makanan, food account, metode inventaris dan pencatatan).

\section{Pengukuran Faktor Ekologi.}

Gizi salah merupakan masalah ekolagi sebagai hasil yang saling mempengaruhi dan interaksi beberapa faktor fisik, biologi, dan lingkungan budaya. Faktor ekologi yang berhubungan dengan malnutrisi ada enam kelompok yaitu, keadaan infeksi, konsumsi makanan, pengaruh budaya, sosial ekonomi, produksi pangan, serta kesehatan dan pendidikan.

\section{Statistik Vital.}


Salah satu cara untuk mengetahui gambaran keadaan gizi di suatu wilayah adalah dengan cara menganalisi statistik kesehatan. Dengan menggunakan statistik kesehatan, kita dapat melihat indikator tidak langsung pengukuran status gizi masyarakat. Beberapa statistik yang berhubungan dengan keadaan kesehatan dan gizi antara lain angka kesakitan, angka kematian, pelayanan kesehatan, dan penyakit infeksi yang berhubungan dengan gizi. Misalnya angka kematian berdasarkan umur adalah jumlah kematian pada kelompok umur tertentu terhadap jumlah rata-rata penduduk pada kelompok umur tersebut setiap 1.000 penduduk. Manfaat data ini mengetahui tingkat dan pola kematian menurut golongan umur dan penyebabnya. Misalnya angka kematian umur 2-5 bulan, umur 1-4 tahun, umur 1324 bulan. Angka kesakitan dan kematian akibat penyebab tertentu, angka penyebab kematian pada umur 1-4 tahun merupakan informasi penting untuk menggambarkan keadaan gizi di suatu masyarakat. Kita lanjutkan dengan statistik layanan kesehatan misalnya Posyandu, Puskesmas, dan Rumah Sakit, berikutnyalnfeksi yang Relevan dengan Keadaan Gizi. Statistik vital ini hanya berupa data pendukung, masih harus dikaji faktor-faktor lain yang berhubungan sehingga status gizi dapat ditentukan dengan akurat. Seperti metode yang lain statistik vital mempunyai kelemahan antara lain : data tidak akurat, adanya kesulitan dalam mengumpulkan data, dipengaruhi oleh kemampuan menginterpretasikan data secara tepat.

\section{DAFTAR PUSTAKA}

http://bppsdmk.kemkes.go.id/pusdiksdmk/wp-content/uploads/2017/08/Ilmu-Gizi-KeperawatanKomprehensif.pdf

http://gizi.fema.ipb.ac.id/wp-content/uploads/2015/02/FUNGSI-DAN-KEBUTUHAN-ZAT-GIZI_edit2YFB.pdf 